\title{
Employment-oriented Knowledge Reconstruction of English Teachers in Higher Vocational Colleges
}

\author{
Hongbin LI \\ Foreign Language Department of Jilin Business and Technology College \\ Changchun City, China \\ Email:lihongbin1975@163.com
}

\begin{abstract}
With the in-depth development of domestic economy and the increasing international communication, foreign language learners are provided with more space and opportunities to perform their knowledge and skills, which also enables domestic English teacher to face a deep reform and further development opportunities. With development and opportunities coexisting at the same time, higher vocational college English teaching has caused a universal attention of society, education departments and English teachers. The goal to cultivate talents of higher vocational education taking the employment as the guidance makes it become inevitable to reconstruct knowledge become in knowledge structure for the college English teachers. In the process of knowledge reconstruction of English teachers in higher vocational colleges, some of the higher vocational colleges carry out the goal slowly and passively. Different majors require student to possess different English skills, so, there still exist problems such as difficulty in knowledge reconstruction and low enthusiasm of teachers. In terms of the problems, this paper puts forward some methods to effectively reconstruct the knowledge systems of teachers, including attention of leaders, partial reconstruction, major penetration and coordination and distribution of responsibilities
\end{abstract}

Keywords-higher vocational colleges; college english teachers; knowledge structure reconstruction

\section{INTRODUCTION}

In recent years, with the development of higher vocational education and frequent foreign economic exchanges, the "three unifications of teaching method", including unification of teaching materials, teaching goals and evaluation standard, have been unable to adapt to the needs of cultivating talents in different majors. Therefore, the education ministry issued "High education English curriculum requirements" in 2009 and put forward that higher vocational college English teaching is not only to help students lay good language foundation, but also to pay attention to training students' practical language skills, especially the ability to deal with business related to future career in English, which has been noted clearly that college English teaching content should be of great applicability and practicality and indicates the goal of the construction of the college English curriculum is to meet the need of talent cultivation.

\section{NECESSITY OF KNOWLEDGE RECONSTRUCTION OF}

\section{ENGLISH TEACHERS IN HighER VOCATIONAL COLLEGES}

The cultivation of professional talents requires teaching content to be closely related with majors. Language is to be used communication tool, which belongs to the category of professional skills in the work. What is required in professional skills in the work should be granted by the teaching. If the content of the course teaching cannot meet the requirements, it is necessary to reconstruct the courses. The course construction cannot be separated from construction of teaching staff, in which the reconstruction of teachers' knowledge structure is very important. Therefore, it becomes inevitable that college English teachers knowledge structure should meet the needs of professional talents. At present, it is an indisputable fact that college English teachers' knowledge structure is unable to meet the needs of professional skill teaching. ${ }^{[1]}$

\section{A. The need of talent cultivation}

Talent training goal determines the curriculum system, curriculum system determines the teaching goal, teaching goal determines the teaching content, and teaching content determines the knowledge and skills that teachers should possess, namely teachers' knowledge structure and ability structure.

Employment-oriented talent cultivation mode makes the knowledge and skills graduates must have become more specific and has a clearer target for college English curriculum, thus, it becomes more accurate to determine the teaching content. At the same time, different professions and jobs have different requirements for English language knowledge and skills, which shows certain differences among various majors.

For example, the requirement of foreign-related majors for students' English language application ability is significantly higher than that of other majors, which is one of the most necessary professional skills required in the work. This shows that foreign-related majors' English 
teachers need both proficiency in the language and familiarity with professional knowledge and skills under the background of vocational guidance, otherwise, the curriculum teaching effect will not be able to achieve the requirement of students' English language application ability.

\section{B. The need of students}

The target of higher vocational education is to cultivate all kinds of specialized talents chased by companies of production, construction, service and management because professional knowledge and skills are the basis to be a specialized personnel. With the increasing opportunities for domestic enterprises to develop internationally, staff at all levels in enterprises have more opportunities to participate in intercultural communication. ${ }^{[2]}$ Employees need to communicate with the outside world in English. For example, in the case of "high-end technical talents", there will be more opportunities to work in the foreign countries, so their English language application ability not only influences the personal career, but also impacts on corporate performance.

\section{The need of English teachers}

Most college English teachers' major in English, which lays a solid foundation for their teaching English. However, they have little chance to learn the knowledge and skills of other majors, basically unfamiliar with the knowledge and skills of other majors. The limited knowledge and skills of English teachers causes congenital deficiencies in other majors and their insufficient knowledge structure. The defect of knowledge structure inevitably leads to them incapably to meet the teaching requirement, especially the ability to deal with business related to future career in English. Therefore, has become the only way for English teachers in higher vocational colleges in our country to enrich the knowledge and skills in other majors, reconstruct the knowledge structure, and meet the requirements of professional talents cultivation for college English course. ${ }^{[3]}$

\section{PROBlems Existing IN KNOWLEDGE RECONSTRUCTION OF ENGLISH TEACHERS IN HIGHER VOCATIONAL COLLEGES}

\section{A. Ambiguous Knowledge Reconstruction Goal of English Teachers in Higher Vocational Colleges}

It is understood that due to various reasons some colleges mainly focus on quality construction of "double division" confined to the professional teaching, so, they show a passive attitude towards college English teachers knowledge structure reconstruction and never put it in practice. There are also a part of schools who explore the college English curriculum reform and replace the college English course with business English. On the whole, college English teachers have their own deficiencies in knowledge structure. Surveys show that quite a number of English teachers think the English teaching effect is not desired, so there is no denying the fact that its main reason lies in here.

\section{B. Different majors have different demand for students' English language skills}

Due to various factor such as the imbalance in target of talent cultivation and regional economic development, different professionals have different demand for students' English language skills, at the same time, some majors have unclear and unspecific requirements for English language skills of students, that is to say, different majors have different demand for students' English language skills.

Those majors which have a clear and accurate requirement for English language skills of students tend to set a relatively clear direction and goal in the reconstruction of the college English teachers knowledge structure, as a matter of course, the knowledge reconstruction is easy to be implemented relatively. Those majors which have a vague requirement for English language skills of students currently should firstly find the necessity and urgency of teachers knowledge reconstruction, can only consider having determine its necessity and urgency of the reconstruction of the college English teachers knowledge.

\section{College English teachers' enthusiasm is different}

In higher vocational colleges, English teachers suffer from the difficulty in scientific research, education, job promotion and treatment. These reasons will more or less affect the working enthusiasm of English teachers, which also makes them feel "marginalized" and totally lose work enthusiasm. At the same time, with the expansion of enrollment, college English teachers often struggle to cope with heavy teaching tasks, so, it is difficult for them to spare efforts to learn knowledge and skills in other majors.

\section{BASIC METHODS OF KNOWLEDGE RECONSTRUCTION OF ENGLISH TEACHERS IN HIGHER VOCATIONAL COLLEGES}

It is necessary and urgent to reconstruct the knowledge structure of English teachers in higher vocational colleges refactoring, but due to the different requirements of various majors, it is difficult to completely copy the operational method of other universities colleges, instead, each college should be based on their actual situation to explore applicable solutions. There are a lot of methods to solve problems in knowledge structure reconstruction of English teachers in higher vocational colleges, but the basic methods can be classified as the following:

1).The higher vocational colleges should recognize the important role of reconstructing English teachers' knowledge structure in improving the quality of talent cultivation and guarantee the quality of talents, then develop plans for the reconstruction of college English teachers knowledge structure and systematically arrange them to participate in regualr communication with the backbone teacher or attend academic conference on specialized course, so as to improve their professional quality and teaching ability. ${ }^{[4]}$

2).Various professional departments in higher vocational colleges teaching should be in accordance with the requirements of higher vocational English teachers to 
send college English teachers to participate in professional practice, investigation and study in a planned way, so as to enable them to be familair with the knowledge and skills in other majors and promote the college English teachers knowledge structure reconstruction. Course teaching quality's unceasing enhancement guarantees the realization of the goal of talent cultivation.

3). According to the professional talent training scheme, it is reasonable to divide college English courses into basic English and industry English, and assign college English teachers into groups of various departments. ${ }^{[5]}$ Teachers who are experienced in teaching and qualified for standard knowledge structure can be elected as the responsor of each major department, in which they plan and integrate the English teaching content and regulate and clarify the definite teaching goal in different stages.

According to professional characteristics and teaching needs, the responsible teachers carry out targeted research activity, regulate every teacher's teaching and lead others to teach responsibly, so as to promote common progress.

4). Some professional teachers who are interested in college English teaching and have a certain language basis can study professional English language knowledge and application skills according to need of the construction of teacher's knowledge structure and realize their language knowledge structure reconstruction, then teach the college English ESP courses. College English teachers' knowledge structure reconstruction is to carry out the spirit of national medium and long-term education reform and development plan outline (2010-2020) and further promote the characteristics of higher vocational colleges. ${ }^{[6]}$

Students' vocational competitiveness and their ability to serve economic and social development needs can be thus improved. College English teachers' knowledge structure reconstruction is helpful to improve the quality of talent cultivation and meet the needs of companies to choose and employ higher vocational education talents.

\section{CONCLUSION}

The teachers' knowledge structure reconstruction is a systematic project. To strengthen and perfect the reconstruction of teachers' knowledge structure is a key in the process of strengthening higher vocational talents training work and a very difficult task in the higher vocational colleges at present, which should cause the attention of the education administrative departments at all levels. The higher vocational colleges should clear their work objectives, formulate practical plans English for teachers' knowledge structure reconstruction, increase the fund's investment, implement various training measures, and earnestly put efforts in English teachers' knowledge structure reconstruction in higher vocational colleges in our country. Thus, it is able to cultivate a large number of high level and high quality talents for social development and the economic development of our country.

\section{REFERENCE}

[1] Zhang Guanzhi, Zeng Hongwei. College English teachers' cultural dilemma, humanistic care and college English teaching $[\mathrm{J}]$. Heilongjiang Researches on Higher Education ,2012,(1):84-85

[2] $\mathrm{Xu}$ Xiaozhen. Higher vocational English professional education theory research in China[M] Beijing: Foreign Language Teaching and Research Press .2006

[3] James-O.Lugo.Life span development [M]. Shanghai: Xuelin Publishing House, 2000,2013.

[4] Luo Yi, Cai Huiping, Wangjin. The application of experiential teaching theory in English writing teaching[J]. 2011(1)

[5] Lei, Xiao. Exploring a sociocultural approach to writing strategy research: Mediated actions in writing activities [J]. Journal of Second Language Writing, 2008, (17): 217-236.

[6] Wiedl, K. H., J. Güthke, \& S.Wingenfeld, Dynamic assessment in Europe: historical perspectives [A], In Jerry S. Carlson (Eds.). Advances in Cognition and Educational Practice: European Contributions to Dynamic Assessment [C], by JAI Press Inc., 1995, (3): 33-82. 